\title{
A Comparative Study of the Educational Aims and Objectives of Chinese Preschool Education Guidance Documents "New Curriculum Compendium" and "Former Curriculum Compendium"
}

\author{
Kyung-chul Kim ${ }^{1}$ and Xiaodan $\mathrm{Jin}^{2 *}$ \\ ${ }^{1,2}$ Department of Early Childhood Education, Korea National University of \\ Education, Taisungtapyunro 250, Heungdeok-gu, Cheongju, 28173, Korea \\ ${ }^{1}$ kbrian@knue.ac.kr, 2*hyodan8666@daum.net
}

\begin{abstract}
This paper conducts comparison and analysis on the two Curriculum compendiums, the guidance documents promulgated by Ministry of Education of the PRC respectively in 1981 and 2001 from the perspective of education curriculum. Set out from the overall direction, educational aims and objectives, of the two Curriculum compendiums, certain similarities and differences are found between the two guidance documents. From the findings, the development path of Chinese preschool education is dissected, thus forming the basic information for understanding Chinese preschool education.
\end{abstract}

Keywords: preschool education, curriculum, compendiums, comparison, China

\section{Introduction}

The preschool education guidance compendium refers to the central and local government documents that regulate the educational activities and preschool activities carried out by preschool institutions like kindergartens, which reflect the preschool education value orientation, and play the role of guaranteeing the rights of child, and guide the development of child scientifically (Y. Q. Yao, Y. Qian, 2013). As the central government document, the "compendium" is a concentrated expression of the Chinese preschool education curriculum, which is also the fundamental and important materials to understand preschool education.

The curriculum is an intermediary or bridge to transfer the thinking and educational theory into educational practice (J. X. Zhu, 2009). Saylor. J. G., Alexander, W. M. \& Lewis, A. J. (1981) defines educational programs as a series of educational opportunities and plans for teaching. The curriculum reflects the learning experience of students through aims and objectives, which is the plan and design of the study, and is performed in the school environment (M. Skibeck, 1984). The curriculum is mainly based on the aims of education, the curriculum content should in line with the spirit of the times and the curriculum structure should be arranged scientifically and rationally, in order to promote the harmonious development of people and meet the needs of the age. Curriculum design should generally consider four factors: the comprehensive aims cultivation, the reasonable curriculum structure, the scientific curriculum content, and personalized curriculum that take care of individual development (S. J. Chen, Q. He, 2011).

The Chinese Ministry of Education issued the guidance document for preschool education in 1981 and 2001: Preschool Education Compendium (Trial draft) (herein

Received (March 26, 2017), Review Result (July 15, 2017), Accepted (January 18, 2018)

* Corresponding Author 
below refers to Former curriculum compendium, FCC)and the "Preschool Education Guidance Compendium (Trial)" (herein below refers to New curriculum compendium, NCC). There are different detailed opinions in dividing the preschool education history after the establishment of China, but the division are basically similar as a whole, J. Z. Tian and J. Yang (2014) divided modern Chinese preschool education history into five phases: preschool education in early stage of China (1949-1956), preschool education in the period of socialist construction (1957-1965), preschool education during the period of the Great Cultural Revolution (1966-1976), preschool education in the new period (19771999), and preschool education in the new century (2000-present). The year of 1981 is the recovery period of preschool education in China after the all aspects of the destruction in Cultural Revolution, and in the new era of development, FCC is the important guidance document of preschool education development in new era. Preschool education in China has entered a new period of development since 2000, that is the development period of the new century, and NCC launched in 2001 is an important guiding document for the development of preschool education in the new century. These two important guidance documents have the same content, but also some different content, education must change with the development of society, and the "unchanged" and "changed" contents are the reflections of the education, society and age.

The analysis on the same and different contents can not only reflects the change process of Chinese preschool education, but also can be referred as a basic material to understand Chinese preschool education curriculum. This study analyzes FCC and NCC from the perspective of education curriculum, and focuses on the fundament of education curriculum: educational aims and educational objectives. It not only analyzes the whole, but also analyzes the details, compares FCC and NCC from two aspects of the overall direction and educational aims and objectives, in order to find out the overall direction of Chinese preschool education and deployment law of education aims and objectives and provide a basic material to Chinese preschool education curriculum research.

According to the aims of the study, the research questions of this study are as follows:

Research Question 1: What are the similarities and differences in the overall direction of the education curriculum embodied by the FCC and NCC?

Research Question 2: What are the similarities and differences between the education aims and objectives of the education curriculum embodied by the FCC and NCC?

\section{Research methods}

Although there is no national unified curriculum standard for Chinese preschool education, the compendium has always been a guiding document to the Chinese preschool education curriculum, representing the Chinese preschool education courses. The educational aims and objectives of this research are Preschool Education Compendium (trial draft) and the "Preschool Education Guidance Compendium (Trial)" issued by Ministry of Education of the People's Republic of China in 1981 and 2001, as well as related academic and dissertations.

This study aims at a comparative analysis of the educational aims and objectives of Chinese preschool education guiding documents NCC and FCC. The general direction of Chinese preschool education curriculum is the basis of analysis. Therefore, this study mainly focuses on the general direction of educational curriculum and the educational aims and objectives of the educational curriculum that presented by the compendiums.

FCC issued in 1981 divided preschool education content into eight parts of life health habits, sports activities, language, ideological and moral, common sense, calculation, music, and art. NCC issued in divided the contents into five parts of health, language, society, science and art. Since the scope of the NCC includes the 
contents of the eight parts of FCC, this research adopts the structure following the division standard of NCC, and summarizes the old eight parts into new five parts. Specific analysis standards are as Table1.

Table 1. Table Label

\begin{tabular}{|c|c|}
\hline $\begin{array}{c}\text { Life health habits } \\
\text { Sports activities }\end{array}$ & Health \\
\hline Language & Language \\
\hline $\begin{array}{c}\text { Ideology and moral } \\
\text { Common sense }\end{array}$ & Society \\
\hline $\begin{array}{c}\text { Common sense } \\
\text { Calculation } \\
\text { Music } \\
\text { Art }\end{array}$ & Science \\
\hline
\end{tabular}

Note: Because the common sense part contains the contents of social field and scientific field as well, therefore divide the content belonging to the social field into society part, divide the content belongs to the science field into science part.

This study performs comparative analysis on FCC and NCC form two perspectives of the overall direction and educational aims and objectives.

\section{Research Results}

\subsection{Overall Direction}

The overall direction of FCC and NCC is shown in Table 2.

Table 2. The Overall Direction of the FCC and NCC

\begin{tabular}{|c|c|}
\hline 1981 & 2001 \\
\hline $\begin{array}{l}\text { OOffer all-round education for child, } \\
\text { including physical, intellectual, moral } \\
\text { and aesthetic education } \\
\text { Preschool for three to six year old } \\
\text { child is an integral part of the cause of } \\
\text { socialist education } \\
\text { Develop child's good living habits } \\
\text { and independent living ability. } \\
\text { Respect the law of child's physical } \\
\text { and mental development, taking games } \\
\text { as the basic activities to prevent } \\
\text { primary school or adult education. } \\
\text { Perform education of "five love" } \\
\text { (that is, love the motherland, love the } \\
\text { people, love labor, love science, love } \\
\text { public property). } \\
\text { Teach child the knowledge and skills, } \\
\text { emphasize on developing a variety of } \\
\text { learning ability, interest and habits }\end{array}$ & $\begin{array}{l}\text { Guide kindergartens to implement } \\
\text { quality education(education for all-around } \\
\text { development) in depth } \\
\text { Preschool education is an important } \\
\text { part of basic education, which is the } \\
\text { foundation of school education and } \\
\text { lifelong education in China. } \\
\text { Kindergarten should work closely with } \\
\text { families, communities, and connect with } \\
\text { primary schools. } \\
\text { Kindergarten should provide healthy, } \\
\text { rich living and activity environment for } \\
\text { child to meet their diverse needs and } \\
\text { enable them to gain experience of physical } \\
\text { and mental development in a happy } \\
\text { childhood. } \\
\text { OPreschool education should respect the } \\
\text { personality and rights of child, taking } \\
\text { games as the basic activities. } \\
\text { OUrban and rural kindergartens should } \\
\text { base on reality, implement quality } \\
\text { education according to local conditions. }\end{array}$ \\
\hline
\end{tabular}


FCC and NCC have three points in common in the overall direction, 1) both focus on the healthy development of child, 2) both respect the law of physical and mental development of child, and take games as basis, 3) both focus on kindergarten and family cooperation.

FCC and NCC in the overall direction of the differences are as follows:

1) The overall direction of the FCC requires child have an all-round education in physical, intellectual, moral and aesthetic development; NCC put forward the concept of quality education. This is inseparable from the background that the concept of quality education" proposed in 1994 in China (B. Liu, 1998), and also the embodiment of Chinese educational thought in preschool education.

2) In the positioning of preschool education, the FCC positioned it as an integral part of the socialist education. NCC refers it as an important part of basic education and the foundation of school education and lifelong education. FCC published in 1981, the socialist reconstruction period, after Cultural Revolution ended in 1976, and the concept of lifelong education in NCC had been proposed in the world in 1965, but because of Cultural Revolution, the introduction of this educational philosophy delayed nearly two decades compared to the developed countries, reform and opening up in 1978 introduced lifelong education ideas and spread it (H. N. Guo, 2013). NCC positioning preschool education as the foundation of life-long education, it is the impact of temporary education thinking. Besides, in previous, although preschool education has been included in education system, it has not become a universal education form. However, it has become an important round of school system now, which reflects the changes in the concept of child.

3) In terms of the health requirements of child, the FCC is more limited to the health requirements of child. FCC also emphasizes on child nutrition, cultivate child's good habits and independent living ability, which is clearly different from the NCC, and it is the traces of the times. In 1993, China canceled food stamps, in 1981 FCC period, China was still in the starving era, so the emphasis on nutrition has not been included in the NCC, which is a small epitome of the times change with epoch-making significance. At the same time, in the 1990s, China experienced long-term war, the whole society in the socialist reconstruction period, the revolutionary color of FCC is more intense, requiring child to cultivate good living habits and form an independent living ability, which violates the law of child development, but it reflects the requirements of the times. NCC clearly put forward the physical and mental health of child, and includes the mental health in the guidance document. This is the understanding and research development of Chinese preschool education in child's psychological, at the same time, FCC and NCC the concept of child, the distinction between preschool education positioning and the requirements of the times can be reflected in it.

4) In the scope of rights, the requirements of FCC are in detail, and NCC is more recapitulative. For example, in NCC, "kindergarten should provide healthy, rich living and activity environment for child, to meet their needs in many aspects of development" This requirement can be refined into a variety of knowledge and skills requirements, ideological and moral education requirements in the FCC. FCC also put forward specific, detailed educational objectives for every level classes, even standard educational aims requirement for "walking, running, jumping". It reflects the decentralization of the FCC and NCC, and if the FCC is the central centralized guidance document, then the NCC only provides a large direction, more power will be placed in locals, kindergartens and other institutions.

5) On the issue of the relationship between kindergarten and primary school, the FCC explicitly propose that prevent kindergarten operates as primary school, NCC requires to 
link the kindergarten with the primary school, it can be seen that the single request has changed into scientific requirements of the two sides, the idea has changed.

6) NCC put forward the "respect the child's personality and rights", which is not included in the FCC content, reflecting the respect for child, and the changes in the view of child.

7) In the urban and rural areas, FCC and NCC reflect big differences, the FCC did not propose different directions according to the different circumstances of urban and rural development, the NCC put forwards that "all kinds of kindergartens in urban and rural areas should proceed from reality and carry out quality education according to local conditions so as to lay a solid foundation for the development of child's whole life. " This is an important change to adapt to the actual situation in Chinese society. Compared to" uniform alignment ", China needs to" adapt its measures to its circumstances "at the current stage.

\subsection{Educational Aims and Objectives}

The FCC and NCC have some changes in educational aims and objectives. As the FCC divides education contents into 8 parts, while the NCC divides it into five areas. Therefore, in analyzing sub-objectives, in order to include educational objectives both, the educational objectives are referred to each part / area.

\subsubsection{The Overall Aims of Education}

A comparison of the overall educational aims between FCC and NCC is shown in Table 3.

Table 3. The Overall Aims of FCC and NCC

\begin{tabular}{|c|c|}
\hline 1981 & 2001 \\
\hline $\begin{array}{l}\text { Offer all-round education for child } \\
\text { Make child grow vigorously in mind } \\
\text { and body. }\end{array}$ & $\begin{array}{l}\text { OImplement quality education. } \\
\text { OBuild the foundation for the child's } \\
\text { whole life. } \\
\text { OTo meet the needs of child. }\end{array}$ \\
\hline $\begin{array}{l}\text { OCultivate new generations who have } \\
\text { the ideal of communism, morality, } \\
\text { knowledge, physical strength, } \\
\text { determine to contribute to the people, } \\
\text { contribute to the motherland and to } \\
\text { mankind. }\end{array}$ & $\mathbf{X}$ \\
\hline $\mathbf{X}$ & $\begin{array}{l}\text { Create good conditions for the } \\
\text { development of child. }\end{array}$ \\
\hline $\mathbf{X}$ & $\begin{array}{l}\text { Promote personalized development } \\
\text { for every child. }\end{array}$ \\
\hline
\end{tabular}

Note: X means no relevant content.

Similarities: 1) The educational aims both include all-round development of child, 2) both including the physical and mental health of child. 3) both regard preschool education as the basic part of education.

Through the comparison of the general aims of FCC and NCC, we can see several major differences: 1) changes from the thought of "all-round physical, intellectual and aesthetic development", to the educational guiding ideology of "quality education". 2) 
The aims of preschool education changes from "builds the foundation for elementary school" to" the foundation for the development of whole life of child. 3) The educational objectives of "educating newcomers of era" to "focusing on individualized child". In the FCC "Chinese education is to cultivate a generation of great ideals of communism, with morality, knowledge, strength and determination to make contributions to the people, make contributions to the motherland, make new contributions to mankind, and lay a good foundation for creating new generation. " The educational objectives of cultivating newcomers in FCC hasn't been explained clearly in NCC, but more aims at the development of child, such as" work together to create good conditions for the development of child and promotes the personalized development of every child. "Such objectives are not expressly expressed in the general education objectives of the FCC.

\subsubsection{Specific Educational Objectives}

Compare the specific educational objectives of the FCC and NCC respectively in five major areas of health, language, society, science and art according to the dividing criteria of NCC.

Table 4. Educational Objectives of FCC and NCC in the Field of Health

\begin{tabular}{|c|c|c|c|}
\hline \multicolumn{2}{|r|}{1981} & \multicolumn{2}{|r|}{2001} \\
\hline $\begin{array}{l}\text { Life } \\
\text { health } \\
\text { habits }\end{array}$ & $\begin{array}{l}\text { Teach some simple common } \\
\text { sense of life to child, and } \\
\text { cultivate good healthy habits and } \\
\text { independent living ability. }\end{array}$ & & $\begin{array}{l}\text { Good health, } \\
\text { emotional stability and } \\
\text { happy in collective life. }\end{array}$ \\
\hline $\begin{array}{c}\text { Physical } \\
\text { sports }\end{array}$ & $\begin{array}{l}\text { Exercise body to promote } \\
\text { their normal development and } \\
\text { improve their ability to adapt to } \\
\text { the natural environment and } \\
\text { enhance their physical fitness. }\end{array}$ & Health & $\begin{array}{l}\text { hygiene habits and basic } \\
\text { self-care skills. } \\
\text { OLike to participate in } \\
\text { sports activities, } \\
\text { coordinate and flexible } \\
\text { movement. }\end{array}$ \\
\hline
\end{tabular}

The objectives of health knowledge and health habits in the FCC education objectives are reflected in the NCC. Both the FCC and the NCC emphasize on the learning of health knowledge and the development of healthy habits. As for the education objectives of the living ability of child, the FCC requires "to cultivate an independent living ability", which is obviously not in conformity with the law of development for child. It changes into "have basic self-care ability" in NCC. It can be seen that in 1981, after the war and the turmoil in China, the requirements for child exceeded the development level of child and placed too much emphasis on the independence of early childhood. But the objectives of health field in the NCC is more in line with that the level of development of child.

Table 5. Educational Objectives of FCC and NCC in the Field of Language

\begin{tabular}{|l|l|l|l|}
\hline \multicolumn{2}{|c|}{1981} & \multicolumn{2}{|c|}{2001} \\
\hline L & $\begin{array}{l}\text { OTraining child to pronounce } \\
\text { clearly, correctly, and learn to }\end{array}$ & L & $\begin{array}{l}\text { OCommunicate with people politely and } \\
\text { positively. }\end{array}$ \\
a & speak Mandarin. Enrich child's & a & OListen to each other's speech. \\
n & vocabulary, and develop early & n & OCan say what he or she wants to say \\
g & childhood thinking and oral & g & OCarly. \\
u & language expression skills. & u & OLike to listen to stories, read books. \\
a & Initially develop child's interest & a & OCan understand and speak mandarin \\
g & in literature Ethnic minority & g & OCan und \\
e & $\begin{array}{ll}\text { child should learn their own } \\
\text { national language. }\end{array}$ & e & \\
\hline
\end{tabular}


NCC cancels the objectives of clear and correct pronunciation in FCC and adds the objectives of polite communication, and listening to other's talking.

Table 6. Educational Objectives of FCC and NCC in the Field of Society

\begin{tabular}{|c|c|c|c|}
\hline \multicolumn{2}{|r|}{1981} & \multicolumn{2}{|r|}{2001} \\
\hline $\begin{array}{l}\text { Ideology } \\
\text { and } \\
\text { morality }\end{array}$ & $\begin{array}{l}\text { Conduct preliminary } \\
\text { five-love } \\
\text { develop child with good } \\
\text { moral and civilized } \\
\text { behaviors and lively and } \\
\text { cheerful characters. }\end{array}$ & & $\begin{array}{l}\text { Participate in various activities } \\
\text { imitatively, and have self-confidence. } \\
\text { Be willing to interact with people, } \\
\text { learn from each other, cooperate and } \\
\text { share, be compassionate; } \\
\text { Understand and follow the basic }\end{array}$ \\
\hline $\begin{array}{c}\text { Common } \\
\text { sense }\end{array}$ & $\begin{array}{l}\text { Enrich child's } \\
\text { knowledge of the } \\
\text { community and expand } \\
\text { the horizons. Cultivate the } \\
\text { interest in knowing society } \\
\text { and the desire for } \\
\text { knowledge, and gradually } \\
\text { form a correct attitude } \\
\text { toward people and things } \\
\text { around the child. }\end{array}$ & $\begin{array}{l}\mathbf{0} \\
\mathbf{c} \\
\mathbf{i} \\
\mathbf{e} \\
\mathbf{t} \\
\mathbf{y}\end{array}$ & $\begin{array}{l}\text { rules of social behavior in everyday life. } \\
\text { Trying to do something in ability } \\
\text { limit, without fear of difficulty, with } \\
\text { initial sense of responsibility. } \\
\text { OLoving parents, elders, teachers and } \\
\text { peers, love collectives, love hometown } \\
\text { and love the motherland. }\end{array}$ \\
\hline
\end{tabular}

FCC and NCC have the same educational objectives in the field of society, which are about child's moral character training and emotional cultivation of society, but the details are very different. First of all, the regulations of FCC on five-love Education reflects the spirit of the era, but NCC has no content about five-love, just contains some related content, and set specific objectives for child in connecting people, hometown and so on.

Table 7. Educational Objectives of FCC and NCC in the Field of Science

\begin{tabular}{|c|c|c|c|}
\hline \multicolumn{2}{|r|}{1981} & \multicolumn{2}{|r|}{2001} \\
\hline $\begin{array}{c}\text { Common } \\
\text { sense }\end{array}$ & $\begin{array}{l}\text { OEnrich child knowledge } \\
\text { of nature to broaden their } \\
\text { horizons. }\end{array}$ & & $\begin{array}{l}\text { Interested in things, phenomena } \\
\text { around, and have curiosity. } \\
\text { Use a variety of senses, use hands }\end{array}$ \\
\hline Calculation & $\begin{array}{l}\text { Teach child to master } \\
\text { concepts of the numbers } \\
\text { within } 10 \text { and learn some } \\
\text { knowledge of count, } \\
\text { geometry, time and space. } \\
\text { Develop child's interest in } \\
\text { calculation, initial logical } \\
\text { thinking, cultivate the } \\
\text { accuracy, flexibility and } \\
\text { agility of child's thinking. }\end{array}$ & $\begin{array}{l}\mathbf{S} \\
\mathbf{c} \\
\mathbf{i} \\
\mathbf{e} \\
\mathbf{n} \\
\mathbf{c} \\
\mathbf{e}\end{array}$ & $\begin{array}{l}\text { and brain to explore problems. } \\
\text { Communicate in appropriate way } \\
\text { and communicate the process and } \\
\text { results of the exploration; } \\
\text { Experience the quantitative } \\
\text { relationship between things in life } \\
\text { and games and experience math } \\
\text { important and interesting; } \\
\text { Have a preliminary environmental } \\
\text { protection. }\end{array}$ \\
\hline
\end{tabular}

The NCC made specific extensions from the proposal of FC "developing the child's attention, observation, memory, imagination and language expression." Relevant educational objectives for sustainable development have been added to the NCC, such as "close to nature, cherish natural resources and have initial environmental awareness." However, the FCC requires "to cultivate child's interest in knowing nature and seeking knowledge" and pay attention to the exploration and knowledge of nature. However, the NCC does not emphasize the knowledge of nature but focuses on nurturing child's 
curiosity about the surrounding things. For the concept "nature", NCC focuses more on the educational objectives of love and protection.

The FCC listed the calculation separately as an educational component that requires the development objectives for child in calculating, but the NCC has no field of "calculate", which has been included in the "science" field. Compared with the objectives of the FCC "count, geometry, time, space" and "accurate, flexible and agile" educational objectives of child's computing ability are set. The "sciences" in the NCC focus more on developing child's exploring and thinking abilities, but also "experience the quantitative relationship between things in life and games and experience the importance and interest of math. Change from rigid mathematics learning to feeling and interests cultivation that more in line with the law of early childhood development, starting from the actual experience.

Table 8. Educational Objectives of FCC and NCC in the Field of Art

\begin{tabular}{|c|c|c|c|}
\hline \multicolumn{2}{|r|}{1981} & \multicolumn{2}{|r|}{2001} \\
\hline $\begin{array}{l}\text { Mu } \\
\text { sic }\end{array}$ & $\begin{array}{l}\text { Teach child to sing, dance, know the details } \\
\text { and skills. Initially develop child's interest in } \\
\text { music, dance and rhythm. }\end{array}$ & $\mathbf{S}$ & $\begin{array}{l}\text { Can initially feel and } \\
\text { love the beauty of the } \\
\text { environment, life and art; }\end{array}$ \\
\hline Art & $\begin{array}{l}\text { On the basis of observing shape, color, } \\
\text { structure. Train child's interest in fine arts } \\
\text { and the appreciation of the beauty of nature, } \\
\text { social life, art works. Develop child's } \\
\text { observation, imagination and creativity, } \\
\text { develop coordination and flexibility of hand } \\
\text { muscle movements, and acquire initial skills } \\
\text { in using art tools and materials. }\end{array}$ & $\begin{array}{l}\mathbf{o} \\
\mathbf{c} \\
\mathbf{i} \\
\mathrm{e} \\
\mathbf{t} \\
\mathbf{y}\end{array}$ & $\begin{array}{l}\text { OLike to participate in art } \\
\text { activities and be able to } \\
\text { express their emotions and } \\
\text { experiences boldly; } \\
\text { Perform art } \\
\text { performance activities in } \\
\text { the way the child like. }\end{array}$ \\
\hline
\end{tabular}

NCC cancels all the skills training in the field of "art", such as the "music" and "art" content in the FCC "to teach child superficial details and skills of singing and dancing ", education objectives of "preliminary grasp of the use of art tools and materials". It only requires "artistic performance in the way the child like." FCC focuses on child's art appreciation, observation, imagination and so on. NCC focuses on developing child's interest in art and freedom of expression.

\section{Conclusion and Suggestion}

The aims of this study is to compare FCC released by Ministry of Education in 1981 and NCC in 2001 from two aspects of the overall direction, educational aims and objectives, in order to find out the overall direction of Chinese preschool education and deployment rule of education aims and objectives. According to the aims of the research, the conclusions are as follows:

\subsection{Overall Direction}

In overall direction, FCC and NCC show the common ground in the basic idea of child development and education, the idea that preschool education requires family cooperation.

There are many differences between the FCC and the NCC in the overall direction. To sum them up, the following conclusions as follow:

1) NCC has proposed some new concepts such as "quality education", "lifelong education" and "convergence of kindergarten and primary school" (X. D. JIN, K. C. KIM, 2017). At the same time, NCC is influenced by the constructivism theory and put forward some new ideas, which shows the national cognition on preschool education has changed, it not only the development of preschool education, but also the progress. 
2) The alternation of FCC and NCC has fully highlighted the characteristics of the era, it can be seen that the changes of the times have impact on the overall direction of preschool education in terms of the health of child and the requirements for the independence living ability.

3) With the change of Chinese society and the development of preschool education, FCC and NCC alternately reflect the change of the view of child. At the same time, from the state's unified planning and requirements to the decentralization of power, considering the differences between urban and rural areas, develop preschool education based on practical condition, these are the changes of FCC and NCC in the overall direction, reflecting the needs of the country, society and the era.

\subsection{Aims and Objectives}

In educational aims and objectives, FCC and NCC have three common points and different points. Three common points are: 1) The educational aims both include the full development of child. 2) Both include child's physical and mental health growth. 3) Refer the preschool education as the basic part of education.

The three major differences are: 1) Change from the thought of "all-round developed physical, intellectual, moral, aesthetic education" into the guiding ideology of "quality education". 2) The aims of preschool education expanded from "the foundation for primary school" to "the foundation for the development of child's whole life". 3) The educational objectives changes from "cultivate new people for the era" to "focus on individualized child".

Based on the commonalities and differences in the educational objectives, there is a certain law on the educational objectives of the FCC and NCC. First of all, it can be seen from educational objectives in the health area: 1) Both FCC and NCC focus on health knowledge and hygiene training of child. 2) In living ability cultivation, FCC requires child have the independent living ability earlier, which does not comply the law of child development, and this was inextricably linked with the era when China had just experienced war and social unrest. 3) NCC targets child's mental health education and reflects the development of preschool education. In the field of language, FCC and NCC alternately reflect the thought of uniform planning to respect for individual development. At the same time, the focus changes from knowledge and skills to communication. In the social field, NCC pays more attention to the cultivation of child's morals and specific codes of conduct than the FCC. FCC more focuses on child's cognition of society, such as "what is the general type of work in society, what the workers do in each kind of work."

Secondly, in the science area, FCC and NCC alternately reflect three major changes: 1) In the field of education of nature, from knowledge instilling into the training of protecting nature and environmental awareness. 2) In mathematics education, from rigid mathematics learning to feeling and interests cultivation that more in line with the law of early childhood development, starting from the actual experience.

Thirdly, In the art area, FCC focuses on the cultivation of skills and abilities; NCC emphasizes the cultivation of interests and the free expression of art.

By comparing the similarities and differences between FCC and NCC, it can be seen that there are some "changed" and "unchanged" contents, and the reasons are various. The issue of the compendium is a national requirement, with the gradual decentralization of power to local and kindergartens; it is even more necessary to perform follow-up study to correctly understand the compendium. Through continuous research and exploration, understand Chinese preschool education deeper.

\section{Acknowledgments}

This paper is a revised and expanded version of a paper entitled [A Comparative Analysis on the New Curriculum Compendium and the Former Curriculum Compendium, 
the Guidance Documents for Chinese Preschool Education] presented at [The 9th International Conference on Advanced Science and Technology (AST 2017), InterContinental Hanoi Westlake, Hanoi, Vietnam, February 9 - 12, 2017].

\section{References}

[1] M. Skibeck, "Readings in School-based Curriculum Development", Harper \& Low, London, (1984).

[2] J. G. Saylor, W. M. Alexander and A. J. Lewis, "Curriculum Planning for Better Teaching and Learning $\left(4^{\text {th }}\right.$ eds $)$ ", Rinehart and Winston, New York, (1981).

[3] X. D. Jin and K. C. Kim, "A Comparative Analysis on the New Curriculum Compendium and the Former Curriculum Compendium, the Guidance Documents for Chinese Preschool Education", Proceedings of the 9th International Conference on Advanced Science and Technology (AST 2017), Hanoi, Vietnam, (2017) February 9-12.

[4] S. X. Chen and Q. He., "International Comparison of Kindergarten Curriculum", Southwest China Normal University Press, Chongqing, (2011).

[5] H. N. Guo, "Study on China's Lifelong Education Policy Based on the Analysis of Policy Texts", Unpublished Doctoral Dissertation. East China Normal University, Shanghai, (2013).

[6] B. Liu, "Liu Bin talked about quality education", Beijing Normal University Press, Beijing, (1998).

[7] J. Z. Tian and J. Yang, "Chinese and Foreign History of Preschool Education", Beijing Normal University Press, Beijing, (2014).

[8] Y. Q. Yao and Y. Qian, "A Comparative Study of the Guidance Compendium between Chinese and American Preschool Education-Taking Shanghai and New York for example", Journal of Educational Development, (Second half)., vol. 7, (2013), pp. 85-88.

[9] Ministry of Education of the People's Republic of China, "Preschool Education Compendium (Trial draft)", (1981).

[10] Ministry of Education of the People's Republic of China, "Preschool Education Guidance Compendium (Trial)", Beijing Normal University Press, Beijing, (2001).

[11] Department of Basic Education of the Ministry of Education of People's Republic of China, "The Interpretation of Preschool Education Guidance Compendium (Trial)", Phoenix Education Publishing, Nanjing, (2002).

[12] J. X. Zhu, "Preschool Education from the Perspective of Constructivism", East China Normal University Press, Shanghai, (2009).

\section{Authors}

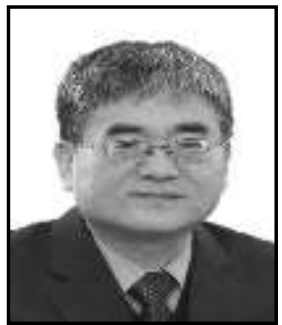

Kyung-chul Kim, Professor, Department of Early Childhood Education, Korea National University of Education

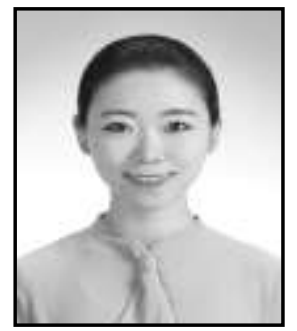

Xiaodan Jin, Ph.D Candidate, Department of Early Childhood Education, Korea National University of Education 